\title{
Moving Around: How Bedouin Villagers in Dubai Respond to the Challenges of Urban Expansion
}

\author{
Anne Kathrine Larsen
}

DOI: 10.21104/CL.2017.2.04

\begin{abstract}
This article examines whether wellknown dichotomous concepts may be of use for understanding social and cultural processes in an era where neoliberal economies and global movements of people, matters and ideas are prevalent. The study focus is on villagers with a Bedouin background on the desert outskirts of Dubai Emirate. The rapid development they have been exposed to during the last decades has caused increased movement between different locations. There will be an examination of how the Bedouin, and especially younger women, experience and relate to these locations. This encompasses in particular how they interpret the desert and how they interrelate to different types of actors in each space.
\end{abstract}

Keywords United Arab Emirates, Bedouin, modernization, space/place, nature/culture

This research is carried out as part of the Norwegian Research Council ISP project no. 222821 "The Hot Lava Edge of Cultural Flows: Global Social Inequality and the Anthropology of Uncertainty, Contingency and Future Orientation" at the Department of Social Anthropology, NTNU. The author gratefully acknowledges both funding support and intellectual stimulation as participant in the project.

Contact Anne Kathrine Larsen, Department of Social Anthropology, Norwegian University of Science and Technology, NTNU-7491 Trondheim, Norway; e-mail: ankala@ntnu.no.

Jak citovat / How to cite Larsen, Anne Kathrine. (2017). Moving around: how Bedouin villagers in Dubai respond to the challenges of urban expansion. Český lid 104, 231-245. doi:http:// dx.doi.org/10.21104/CL.2017.2.04 


\section{Introduction}

When studying the people of a Bedouin background living in villages on the outskirts of Dubai Emirate, ${ }^{1}$ one is bound to notice the spatial aspect of their lives; where they stay, move and how they relate to the places they frequent. In their fast vehicles they quickly oscillate between village, desert and the highly urban Dubai city. They may also go abroad for education, work, holidays and/or medical treatments - but this issue will not be pursued further here. While it is not uncommon for people around the globe to move daily between various locations which are quite far apart (quite the contrary), the spaces regularly used by the villagers in this study have striking differences in their visual and physical appearances that make them stand out at least for the outside observer. In order to find out how the village people relate to the different localities, how they view and use them, I will accompany some of them around in the village and in the desert and have a look at the significance of these locations.

As part of the discussion, I will question whether the analytical concepts of 'nature' versus 'culture' and also the 'space'/'place' divide can shed light on the processes. The 'nature'/'culture' divide has been much criticized as ethnocentric and for being imbued with a universal understanding both of their contents and for the clear-cut opposition between them (see for instance Ortner 1972 and Strathern 1980). If nature alludes to physical and material areas not influenced or processed by humans, culture stands for the opposite, that is, areas highly developed and transformed by human beings. The usefulness of the 'space'/'place' distinction is another matter. While space may refer to the extension of an area, place can indicate the use of and meaning(s) imbued in that location (see for instance Hubbard - Kitchin - Valentine 2005, for an overview of different debates connected to the concepts). While 'nature'/'culture' is in principle not necessarily connected to locations, as I will show, 'nature'/'culture' is intrinsically so.

\section{Background}

In order to understand the present situation and views of people in this village, it is necessary to go back in time a few decades. Most of the inhabitants are people, or descendants of them, who until approximately four decades ago migrated with their animals mainly between a major inland oasis-settlement - where they spent summer - to Dubai, a commercial town located on 
the coast of the Persian Gulf, where they camped during winter. They could therefore be classified as nomads, or semi-nomads, who were also involved in the seasonal farming of dates and even salaried work, such as diving for pearls in the Gulf when this was still a lucrative business. ${ }^{2}$ After the discovery of oil and the foundation of The United Arab Emirates in 1971 - of which Dubai constitutes one of seven emirates (Heard-Bey 1982) - the Bedouin were faced with the possibility of settling permanently. One option was to take up residence in Dubai town, where some of them already owned houses. But when they received an offer from the ruling family to settle in the desert almost $50 \mathrm{~km}$ from the town center, close to some wells where they used to camp on their migration route, this was preferred as it would hopefully give them the better of two worlds. They could continue to live in the desert, with its tranquility, esthetics and other qualities, and also carry on with animal husbandry as well as other farming. At the same time, they were a short distance from Dubai and other towns along the coast, where they could visit, work and enjoy many of the urban facilities. ${ }^{3}$

The people who settled here belonged to many different lineages and tribes. As nationals, they became entitled to receive a free house upon marriage, and funding for their upgrade after several years. Today the permanent inhabitants of the village consist of the Bedouin - a term they apply themselves and which alludes to their cultural background. This encompasses a whole set of elements which greatly connect to their lifestyle, such as livestock farming and a past tradition of nomadism. ${ }^{4}$ There are other people living here, too. Some are married into the village, while others are foreigners who work in the settlement. Some of the immigrants have moved into houses that have been vacated by the nationals as the latter built better houses on the outskirt of the village. Others who work in the village live outside it and only visit during work hours. On the other hand, many of the residents leave the settlement every day to go for work, schooling, shopping, medical services, leisure activities, etc., mostly in or close to Dubai city, as it now should be called.

As the economy rapidly grew as a result of oil and gas revenues, and later on commerce, finance and tourism, significant changes took place in the emirate of Dubai. On the physical side, a lot of construction work was carried out transforming the former town into a continuously growing metropolis, culminating in its present high-rise buildings, shopping malls and leisure establishments. On the demographic side, a new group of people appeared in the country, namely the immigrant workers. These were both blue and white collar workers from

2 See for instance Heard-Bey (2001) on the traditional economy of the UAE.

3 It can be mentioned that the Bedouin of the United Arab Emirates appear as more central citizens of their new nation than for instance their counterparts in Kuwait as described by Longva (2006).

4 People in the village are labelled by themselves and other Emiratis as Bedouin, which primarily refers to their immediate past as nomadic animal herders. They do, however, see themselves as carriers of a whole complex of qualities that characterize them as a group. 
Asia, but also from other parts of the world, supplying the country with the necessary labor. Today the immigrant population constitutes as many as nine out of ten people living in Dubai. Of more recent origin are the tourists who now flow into the country, albeit on a more temporary basis. On the economic side, this development provided increased opportunities for nationals to hold managerial positions in the public sector, as well as establishing businesses - also together with foreigners - on favorable terms for themselves. ${ }^{5}$ Since independence, the level of education has also increased steadily, creating more and more professional nationals. And materially, the standard of living has improved significantly for the Emiratis. Not only do they have access to high incomes, but they also enjoy many privileges (economic, legal, etc.) which place them in a further favorable position. Finally, they are able to benefit from high-standard health services and quality educational institutions either locally or abroad.

Turning to the Bedouin village, this can be observed in practice. Today's villagers are employed in various sectors. While many of the men, especially the older ones, are said to "work for the sheikhs" (holding positions connected, for instance, with their race horses and falconry), quite a few of the younger men are employed in the military or in the police force. While some men work with the government, others are involved in private businesses of various sorts, such as owning small shops in the village, and some engage in both. Some of the younger village women are also employed in the public sector (teachers, administrative officers), while Emirati women in general are rarely employed in the private sector (Mourtada-Sabbah et al. 2008). At the same time, the Bedouin families keep animals. As they are no longer nomadic, the livestock (cattle, sheep and goats) are kept on farms in the surrounding desert where they are tended to by immigrant workers. The camel farms are of special interest to the villagers. They supply both meat and milk, but some of the camels are used primarily for racing - a highly appreciated activity during winter. As the use of camels as transport animals ceased, they could instead provide a certain contribution to the Bedouin's income through the prizes they collected in races. When other sources of income became more important, the racing camels were mostly kept for the sake of excitement although the prizes are still valued (Khalaf 1999; 2000). The farm products are primarily meant to meet the family's own needs, and are not intended for sale. Although the manual labor on the farms is carried out by immigrant workers, they are under supervision by the villagers who visit their farms every day. Tending to the animals was traditionally the women's domain. This may still be the case, but the camels are today a male domain. In any case, the farms are mainly the responsibility of more senior family members. The same is true for the date farms which are adjacent to the animal farms.

5 As government positions in the U.A.E. have become overcrowded by Emiratis and the neoliberal emphasis on merits before social connections in the labor market has increased, the government encourages nationals to seek higher education and qualify for jobs within the private sector (Bristol-Rhys 2010: 9-10; Kanna 2010). 
The villagers live in compounds enclosed by high walls. These are inhabited by patrilineal extended families, nuclear families or a combination of the two. One version is the presence of several nuclear units in separate dwellings inside the compound. In addition to the senior couple with their unmarried children and perhaps also their recently married son and his family, the other dwellings are each inhabited by a married son with his wife and children. The compound has a common kitchen where hot meals are prepared and carried to each unit, although these also have separate kitchens. But members from the different sub-units sometimes eat together with other family members in their parents' house. In other cases the separate units are not situated within a compound, but may be placed adjacent to each other along a village street, thus making the family units neighbors. And again, one might find nuclear families who are not related to their neighbor at all. Although the nuclear family is the main economic unit, there is in any case a certain amount of pooling of resources and sharing among close family members. The farm products are distributed to the extended family, but may also be given as presents to others, such as female kin who are married out of the compound or village.

As touched upon, the villagers are - as with other Emiratis - surrounded by and quite dependent on immigrant workers. They are servants, nannies, cooks, drivers, watchmen, tailors, tradesmen running the small village shops, farm laborers, teachers, health workers, cleaners etc. The majority of them are men, and they are quite visible in the village landscape when they move about in cars and lorries, or by foot.

\section{The Approaching City}

As mentioned, the Bedouin decided to settle in the desert outside town. As time went by, the urban area of Dubai expanded outwards. In addition, several satellite areas were constructed outside the main urban settlement. Taking the highway from Dubai towards the village, one passes by both university campuses and a couple of huge shopping malls, to mention just some of the establishments. Coming closer to the village, one noticeable feature is all the infrastructure set up in connection with camel races. An existing racetrack next to the settlement has been upgraded and made into the main racecourse in the emirate. This led to the building of camel pens adjacent to the village, as well as a shopping and service center close by to cater for the camel-racing activities. The village is located about one kilometer from the highway, and the side road running through it continues towards several horse stables belonging to members of the ruling family. A center for falconry, also belonging to the ruling family, is situated nearby. A little further on one can find a cycling course, an airport for prop-plane sightseeing, a five-star hotel and spa as well as a system of linked artificial ponds for outings in the desert. This is to mention only the major projects. 
Due to such activities, there is an increasing number of strangers around who make the villagers feel insecure. The very idea of setting up a village away from the tumult of the city, with people who shared the same background as them, was an impetus for choosing this site in preference to areas in town where they - as mentioned - used to stay in winter and where some of them already had houses. Both the construction work and the running and maintenance of new projects demand much labor. Strangers, workers or visitors, who are connected with the new projects, pass by and also stop in the village. The villagers say that they cannot trust these people, who they associate with criminality and other unwanted behavior. Although the inhabitants have for decades experienced the presence of strangers when going to the city, they now feel the menace on their own doorstep. Whether the threat is real or not is not the question. The point is that the villagers are preoccupied with the matter and voice their concerns frequently in conversations.

It is also true that the villagers show a certain excitement about this development. It makes the village famous, they say. It also provides work for the male population, such as at the centers for camel racing, horse racing and falconry, and also at a nearby military training camp. These are all fields where the traditional expertise of the Bedouin can be put to use. At the same time, all these construction activities bring with them a lot of upheaval. There are vehicles driving through the settlement at all times of the day, which makes the place busy and noisy. They also have an idea about increased pollution as a result of the development. The Bedouin enjoy the silence of the desert. One of their favorite pastimes is going out into the desert, usually close to their nearby farms. Apart from making a barbeque and chatting, they enjoy walking in the sand and feeling the fresh air, as well as looking at the moon and stars at night. The pure air, as they perceive it, is valuable and I will return to this later.

As the village expands as a result of natural growth, more houses are also built by the inhabitants. Some of them are erected on the outskirts of the main village and are situated as enclaves in the nearby desert. Such arrangements enable villagers to live in more seclusion from outsiders. As one young woman said to me one evening when we were sitting in the sand outside her family compound - which is situated outside the central village and which actually made up a whole hamlet composed of her extended family; "Before we lived in the old part of the village. After we relocated, I enjoyed being able to move freely about without the risk of being seen by strangers”. She alluded to the practice of women avoiding close proximity to males outside the immediate family. 


\section{Moving Around}

The challenge young Emiratis in particular face is how to participate in a highly modern and dynamic ${ }^{6}$ economy as active and responsible professionals, where various sorts of consumerism are emphasized and readily available, and at the same time take into account their ethnic and cultural background and values. This is handled in various ways, as solutions are found in both public behavior and private conduct.

As mentioned, the Emiratis face a situation of economic dependency on foreigners, and to a certain extent also a physical proximity to them out of necessity. The foreigners are of course a heterogeneous group regarding education, income, ethnic background and position in the country, something the villagers also acknowledge. Still, they often see and talk about the expatriates in general terms, who may thereby serve a role as their moral other. Foreigners in general are associated with unreliability and theft, and the villagers feel insecure - especially when visiting the city. As one informant said: "Dubai has fine restaurants now, but the place is unsafe." Prostitution is another issue which classifies foreigners as immoral, as prostitutes are seen as bad women who bring along contagious diseases which they transmit to local men. As mentioned, the behavior of foreigners, their clothing and other visible conduct, are often such that the villagers think they have a bad influence on their children. ${ }^{7}$ And as another villager said: "We do not mind foreigners, but they must behave." Tourists as a whole are seen as more acceptable as they only visit briefly while the immigrant workers - personified as 'Indians' - are thought to bring more trouble. The villagers are also skeptical of immigrants working in the village, and may suspect them of theft. With construction work and new projects in the vicinity, the traffic passing through the village has increased and also strangers stopping by, which is even more threatening. The immigrant laborers are physically present everywhere in people's daily lives, but the intercourse between the Emiratis and them seems mainly to be limited to purely work-related matters. Apart from that, they primarily constitute extras on the scene, belonging very much to a different category. Exceptions in the village are the expatriate teachers and health workers, who occasionally socialize with the locals.

The foreigners in Dubai, then, are not seen as part of the Emirati in-group, which constitutes a certain moral community and where a certain common identity is shared. They are frequently used as a prototype for the immoral. The notion of "the stranger" as introduced by Simmel (1971) may fit the

6 Davidson describes Dubai's economy as subject to a 'high-risk strategy' in comparison with Abu Dhabi's 'low-risk strategy' (2008).

7 Anh Nga Longva argues that the use of the abaya (black cloak) among Kuwaiti women is not so much an expression of religious necessity as a demonstration of otherness in relation to the immigrants (Longva 1993). 
foreigners as experienced by the villager. They are definitely part of the society, but still outsiders. This implies a position of closeness and remoteness at the same time. Those who are most significant for the reputation of the villagers, however, are not the foreigners, but other nationals, especially the tribal Arabs. And here we encounter an interesting point; members of their own ingroup are also those towards whom their behavior and reputation are mostly guarded. For women this implies keeping a certain distance to men outside the immediate family, obtained if necessary through veiling. This behavior is practiced more ardently when other nationals are around. ${ }^{8}$

Even though modern ways of living - such as access to consumer goods, services and various entertainment - are greatly preferred and idealized by younger village women, ${ }^{9}$ practical matters have to be taken into consideration for obtaining such a lifestyle. This ranges from how to move around in a safe and decent way, which is necessitated by having employment, going shopping and enjoying leisure activities outside the village, to their desire for global fashion and elegant style of clothing within the demands of being decently covered. The women have found ways of addressing these issues, but their solution is nevertheless not the same as, for example, for Western women - who many of them see as too exposed and lacking various protection. Young girls occasionally dress in Western-style teenage-clothes, but only inside the "safe" parts of the house where nobody except themselves can see them. This can be done in a playful way through mimicry, where they imitate the poses and expressions of popular singers and dancers. This creates an identity with, but also a distance from the image, rendering it harmless (see Moore 2011). Young women use the global image of the modern woman to position themselves, by approving and identifying with some aspects, but also through establishing a moral border towards other aspects. In this way, a certain superiority regarding their own appearance is established, although individuals may emphasize that this border should be set liberally as they are 'broadminded people'.

While these and similar ambiguities regarding their present way of life are often expressed in conversations with me, such concerns may lie at the core of another aspect of their everyday life, namely the great interest younger village women display regarding diet and health. This focus is of course part of a global trend in lifestyles, which is brought to women through the media, and as such is nothing peculiar. But the extent to which they are preoccupied with this is striking. The women discuss the ingredients of their dishes, the favorable qualities of traditional food such as camel milk and dates, as well 
as the herbs they grow or collect themselves, how to avoid additives and the side-effects of eating genetically modified food, etc. Such points were constantly brought to my attention with their perceived health effects. ${ }^{10}$ Some of the village women have tried keep-fit classes in town, but for practical reasons this does not seem to be a convenient solution at the moment. Perhaps the final area where protection from the menacing changes in the environment is needed is the purification of their own bodies. When visiting the nearby desert, the health benefits of the sand, like walking barefoot or jogging on it, or putting ones hand down inside it to feel the heat or cold, were also emphasized. This points to the current position of the desert in their culture.

\section{The Physical Environment The Village}

Let us go further into the spaces where people move, pass by or watch from a distance. The village can be said to be located in the desert, as there is yellow sand both surrounding the settlement and partly inside the village. While the sand between the houses is flat, as the top layer of sand was removed when constructing the village and from people and vehicles moving on it, sand dunes start to appear immediately outside the built-up area. Women living on the outskirts of the village may move over to the sand in the late afternoon, where they sit and chat while enjoying a snack. Some bring along mats, while tents and similar provisional structures are also erected to sit in. ${ }^{11}$ Still, I have noticed a certain tendency for the women to sit directly on the sand where they play with it, filter it through their fingers or bury their hands into it. While most of them enter the house in order to perform their late afternoon prayer and return to the outside sitting area afterwards, some actually choose to perform the prayer outside directly on the sand.

For some of the houses located more inside the village, other solutions are found. In many places sand has been brought in to provide decoration between the sidewalks and the houses. This sand has been brought from further inland, where the color is more red than yellow. This sand is considered not only to be more beautiful, but also more fertile. Again, tents are erected on the sand (imported or local) to serve as a type of garden pavilion. The designs of these tents and their mats and cushions are readily inspired by traditional colors and patterns. When the women (neighbors and relatives, who are most often, but not exclusively of the same network) gather here, the servants bring coffee and snacks, first and foremost dates, to be consumed while they chat.

10 Bristol-Rhys states that when Emirati women talk about the merits of food, they pepper their speech with the words 'organic' and 'all natural' (2010: 60).

11 Abu-Lughod (1999: 2, 40) also describes how the settled Awlad 'Ali Bedouin of Egypt erect tents outside their permanent houses in the village. 
The houses in the village have in general increased in size from the time of the first settlements. These homes also include larger patios, where women can meet and move around with less chance of being exposed to men outside of their family than in the more aggregated part of the village. In these patios imported red sand is also used creatively on the ground as part of patterns where it intermingles with tiles and herbal beds. In connection to these new houses, the tent is often replaced by a permanent pavilion with air-conditioning and walls made from one-way windows. A television is also often found here. Nevertheless, in spite of the new architecture, there is still a certain tendency for the women to be drawn to the small sand dunes directly outside their houses. However, this depends on the season and the temperature.

As stated, mainly immigrant laborers are seen walking around the village. Most of them are males, but there are also female servants and nannies with children. Nevertheless, there are some national males and occasionally females found strolling in the village (although they usually leave the housecompound in a car with one-way windows, most often to go somewhere outside the village). The younger women in particular walk about in small groups, most often in the late afternoon or at nightfall. Some state explicitly that they do it for exercise. Apart from enjoying the company of each other, walking with others is seen as decent and proper behavior. Elderly women are not so particular and may walk short distances alone from one house to another. A couple of years ago, a small park was constructed in the middle of the village with palms and bushes, benches, a playground for children and a walking-track around it. The ground is mostly sand, apart from the paved paths. The park has grown popular with the young nationals, although some of the white-collar expatriates in the village as well as the nannies taking the children for a walk also use it as a meeting place. The proximity of the people visiting it constantly changes depending on the nationality and gender of who is there. Here we can note that groups of village girls and younger women, sometimes with children, exercise around the gangway, and also sit down to chat on the benches. Occasionally men might enter the arena, but will stand at an appropriate distance from the women, depending on their relationship.

\section{The Desert}

The Bedouin regularly go to the surrounding desert. Those with farms in the vicinity of the village visit it once or twice a day to supervise the workers there and bring home farm products. This is usually the task of a senior family member. But talking about going to the desert per se normally implies enjoyment and recreation. Younger men go there in order to hunt or enjoy some four-wheel driving in the dunes. Going to the desert can in fact imply several activities, such as for a short afternoon trip, having a barbecue at the farms or staying away for as long as a week or more. These outings are made during 
the cool winter months, and staying for longer periods is often done during the school holidays. The Bedouin will then sleep in permanent structures or tents. When barbecuing, the men and women will sit around separate fires, but can cross over for a short time if the rules of veiling are adhered to. While the Bedouin may be active in preparing the food (such as bread baked in the sand), the drivers also bring out dishes prepared in advance by the servants. The nannies will go along to the desert to look after the smaller children. Those who go camping together are families and relatives, and in general they appear to be quite exhilarated. The women start the late afternoon by walking along the sand ridge before returning to the camp to pray. There is a very good atmosphere when the food is being prepared and then eaten. The children fly kites and play with different equipment located there, such as swings and motorized tricycles. When darkness closes in, they often tell each other stories, and ghost stories are especially popular. If they run out of their own stories, they may download them from their tablet computer and read to the other children.

When camping for several days in the desert, a certain rhythm may establish itself. The eldest man in the (extended) family may lead the other men in the outdoor prayers. When they gather around the fire in the evening, elderly people sometimes recite poems. Again, it must be reiterated that those participating in these outings seem to enjoy them greatly - children and grownups, young and old, men and women. As the time passes, the anthropologist is taught about the herbs and the trees and their healing properties, and likewise about the healing properties of both walking on the sand, praying on it and burying one's hands deep into it.

The villagers are not opposed to alterations made to the desert in principle. Recently, a public lake system was constructed in the area offering opportunities for walking around it and arranging picnics on the shores. Trees have been planted around the lakes, which have attracted many different species of birds. Work has been carried out on the desert to beautify it and make it more attractive, which the Bedouin agree with. They are proud of the "founding father" and first president of the UAE, Sheikh Zayed, who is referred to as "he who made the desert green". They actually see many of the building efforts and installations as positive developments, both for enjoyment and for offering job opportunities. And they share a pride in what has been achieved in the Emirate, although they are skeptical about some of the social changes that go along with it. ${ }^{12}$ What they primarily resent is when the projects come too close to the village, with noise, commotion and, not least, the presence of strangers.

12 There are voices opposing the more liberal turn of Dubai during the last couple of decades in comparison with the other emirates. This includes increased prostitution, a tolerance of homosexuality, access to alcohol, laxity towards food restrictions during Ramadan etc. (Davidson 2008). 


\section{Discussion}

What I have described above are some of the major areas which the Bedouin inhabit. Most of these places are also frequented by other people, either their own countrymen, immigrant workers or tourists - who each attach their own significance to them. The village, although for a long time also inhabited by foreign workers, is increasingly being visited by strangers. The new villas being built are more shielded from outsiders than the original houses. A vital part of their life is the enjoyment of the desert, which the villagers regularly visit, especially during the cooler winter season. Here, too, they may encounter both acquaintances and strangers imbuing their own meanings to the place. For village women especially, however, they can feel rather undisturbed by people they would like to keep at a distance, be it those they know as well as strangers. Through its layout and social rules the desert protects the women and therefore also frees them. Protection creates freedom, as do veils, walls, one-way windows and segregated camps shielded by sand dunes and easy surveillance of the area.

In the village, the homes are oriented inwards with a patio in the middle, or as with the newer, larger houses, the courtyard/garden is in the front of the house surrounded by high walls. This latter version makes it possible for the family - and especially the women - to stay outside without receiving unwanted attention from passers-by. Perhaps because of this, the women do not gather so often at the sidewalks and in the surrounding sand any more. Despite the transfer of sand to the compounds and along the streets, the immediate relation to the desert is less close. Although the joy of a courtyard and garden is experienced in connection with the newer houses, the urge to go to the desert is still there and is realized through the desert outings. Here the women have the opportunity to be undisturbed, as uninvited outsiders seldom visit the camp, ${ }^{13}$ and, moreover, they are able to spot strangers from a distance and can take the necessary measures to avoid unwanted proximity. So as increasing development comes to the village, the houses become more secluded and more remote from the surroundings. By periodically visiting the desert, where seclusion and protection can be maintained, the Bedouin can restore a closeness to the desert.

Analytically, then, we can distinguish three separate spaces used by the younger female Bedouin; the city, the village and the desert. ${ }^{14}$ Although they each have certain interpretations, expectations and rules for interaction with each other as well as with outsiders, one can assume that other users have somewhat different views of the respective spaces. This includes how they 
can move about in each of them, whether and how they can approach strangers, and how to conduct a proper interaction - which for instance may include a certain avoidance of each other. Emirati men, and especially Bedouin males, may show proper, respectful conduct towards women in the village and in the desert, letting the women decide the framing of the contact. While the women may be more lax with the male immigrant workers, the latter will normally exhibit a very reserved and humble attitude towards the village women, so that the latter can feel at ease.

Three different spaces, but each with potentially different meanings for those who use them, create an array of different "places". As their meanings may vary somewhat between different users, so does the idea about proper interaction in each, implying uncertainties. One can imagine a four-wheeldrive car full of tourists with cameras stumbling over a Bedouin camp in the desert, or a group of local men and veiled women encountering scantily dressed expatriates on their way to the beach in Dubai. The distance (physical, social, emotional) villagers express or display towards "the other" may therefore not be seen as an expression of purdah alone or of condescension, but as a strategy to protect oneself from others' unpredictability in the spaces they all inhabit and to a certain degree share, albeit infused with different arrays of meanings. While 'space' denotes a set extension of an area, as a 'place' it is not only socially heterogeneous and multicultural, but also an arena for negotiation, avoidance and potential mismeetings.

Let us turn to the 'nature'/'culture' divide to see whether the desert is thought of as having qualities we link to 'nature' - the physical, unprocessed surroundings untouched by man. This is in contrast with culture, which is associated with something altered and possibly refined by human beings. As we have seen, the desert sand is brought into the village and arranged there, without being spoken of as the desert. Likewise, the Bedouin refashion the desert in many ways by creating tracks in the sands with their vehicles, constructing camps near their farms etc. The border between the desert area and the manmade environment is therefore somewhat blurred. Furthermore, the desert is not viewed as unambiguously attractive; this is after all traditionally the place where spirits are found. In spite of the love for the sand dunes, the green oases, cultivated and monitored by humans, were after all attractive and vital spots in the desert areas. The man-made projects situated in their surrounding desert are readily seen as progress, as a symbol of Dubai's achievements.

But when it comes to some of the qualities they associate with the desert, concepts related to healing properties, purity and cleansing are frequently used..$^{15}$ These concepts are in general often used by the younger generation of health-conscious Bedouin women, who also like to emphasize that 'desert

15 Ideas glorifying the desert are found among the Awlad 'Ali Bedouins of Egypt studied by Abu-Lughod. She describes how they emphasize the good qualities of the desert, and how they are oriented towards the desert rather than to the nearby sea (1999: 40). 
products' such as camel milk and dates are the best nourishment for the body. These are also the farm products given to close relatives, which may reinforce the family's connection with the desert through their common background. Moreover, many Bedouin see themselves as purer Arabs than other countrymen who have mixed-blood due to their intermarriage with non-Arabs. ${ }^{16}$ Many of the women actually express that they prefer a husband from a Bedouin background. In this complex of related concepts one can therefore discern ways of thinking related to the unprocessed, uncorrupted, unadulterated and authentic, in other words, what may be denoted as ingredients in the analytical concept 'natural'. The way this is used by the Bedouin women makes it easy to recognize modern global discourses on health shared by the middle classes across the world. The persistent preoccupation with this matter among younger Bedouin women may however qualify for its own interpretation. As they search to find their place in an unclear, contaminated and potentially threatening environment, they seek to maintain their own purity among others through their diet (cf. Mary Douglas 1984). My conclusion, then, is that there is a certain link between desert and nature, but in this case between the desert and 'the natural'.

\section{April 2017}

\section{References}

Abu-Lughod, Lila. 1999 [1986]. Veiled Sentiments. Honor and Poetry in a Bedouin Society. Berkeley and Los Angeles, London: University of California Press.

Bristol-Rhys, Jane. 2010. Emirati Women: Generations of Change. London: Hurst and Company.

Davidson, Christopher. 2008. Diversification in Abu Dhabi and Dubai: The impact of national identity and the ruling bargain. In: Alsharekh, Alanoud Springborg, Robert (eds.): Popular Culture and Political Identity in the Arab Gulf States. London: London Middle East Institute at SOAS.
Douglas, Mary. 1984 [1966]. Purity and Danger: An Analysis of the Concepts of Pollution and Tabu. London: Ark Paperbacks. Heard-Bey, Frauke. 1982. From Trucial States to United Arab Emirates: A Society in Transition. London and New York: Longman.

Heard-Bey, Frauke. 2001. The tribal society of the UAE and its traditional economy. In: Al Abed, Ibrahim - Hellyer, Peter (eds.): United Arab Emirates: A New Perspective. London: Trident Press Ltd.

16 Bristol-Rhys describes how the Emirati college women she studied talk about 'pure Emiratis' as someone who has lived there for generations and who (should) have a higher status than those who immigrated more recently (2010: 108-109). Urban Emiratis may on the other hand distinguish themselves from desert people, i.e. the Bedouin, who are seen as backward (op. cit.: 121-122). From my own observations I have experienced that among Emiratis, 'Bedouin' may be seen as both honorable and derogatory depending on speaker and context. See Abu-Lughod (1999: 45) for similar ideas among the Bedouin she studied. 
Hubbard, Phil - Kitchin, Rob - Valentine, Gill. 2005. Key Thinkers on Space and Place. London: SAGE Publications Ltd. Kanna, Ahmad. 2010. Flexible citizenship in Dubai: Neoliberal subjectivity in the emerging 'city-corporation'. Cultural Anthropology 25: 1: 100-129.

Khalaf, Sulayman. 1999. Camel racing in the Arab Gulf: Notes on the evolution of a traditional cultural sport. Anthropos: International Review of Anthropology and Linguistics 94 (1/3): 85-106.

Khalaf, Sulayman. 2000. Poetics and politics of the newly invented traditions in the Gulf: Camel racing in the United Arab Emirates. Ethnology 39 (9): 243-261.

Longva, Anh Nga. 1993. Kuwaiti women at a crossroads: Privileged development and the constraints of ethnic stratification. International Journal of Middle East Studies 25: 3: 443-456.

Longva, Anh Nga. 2006. Nationalism in premodern guise: The discourse on hadhar and badu in Kuwait. International Journal of Middle East Studies 38 (2): 171-187.
Moore, Henrietta L. 2011. Still Life: Hopes, Desires and Satisfactions. Cambridge and Malden: Polity Press. Mourtada-Sabbah, Nada - Al-Mutawa, Mohammed - Fox, Johan W. - Walters, Tim. 2008. Media as social matrix in the United Arab Emirates. In: Alsharekh, Alanoud - Springborg, Robert (eds.): Popular Culture and Political Identity in the Arab Gulf States. London: London Middle East Institute at SOAS.

Ortner, Sherry B. 1972. Is female to male as nature is to culture. Feminist Studies 1 (2): 5-31.

Simmel, Georg. 1971. "The stranger" (first published in 1908). In: Georg Simmel: On Individuality and Social Forms: Selected Writings. Chicago and London: The University of Chicago Press.

Strathern, Marilyn. 1980. No nature, no culture: the Hagen case. In: MacCormack, Carol P. - Strathern, Marilyn (eds.): Nature, Culture and Gender. Cambridge: Cambridge University Press.

\section{Stále v pohybu: jak se beduínští vesničané v Dubaji vyrovnávají s následky rozšiřování měst}

Tento článek zkoumá, zda dobře známé dichotomické koncepty mohou posloužit k pochopení společenských a kulturních procesů v době, kdy neoliberální ekonomiky a globální pohyb lidí, věcí a myšlenek jsou běžným jevem. Předmětem zájmu jsou vesničané z beduínského prostředí na okrajových pouštích Dubajského emirátu. Rychlý vývoj, jemuž byli vystaveni v posledních desetiletích, zapříčinil nutnost vyššího množství přesunů mezi různými lokalitami. Bude zkoumáno, jak beduíni, a především mladší ženy, vnímají tato místa a jaký k nim mají vztah. Zvláštní pozornost bude věnována tomu, jak interpretují poušt' a v jakém jsou vztahu s různými typy činitelů v jednotlivých prostorech. 